\title{
Pemberdayaan Orang Tua Dalam Stimulasi, Deteksi Dan Intervensi Dini Tumbuh Kembang Anak Di Masa Pandemi Covid_19
}

\author{
Siti Maryam, Ernawati Tri Handayani, Lintang Kurnia Dewi, Yuni \\ Khofifah Kurniawati
}

Universitas Tulungagung dan maryammyamsk@gmai.com, erna.th29@gmail.com, kurnialintang520@gmail.com, yunikurnia2308@gmail.com.

\begin{abstract}
Growth and development in infancy and toddlerhood is a very important process for a person's life. The first five years are commonly referred to as the golden period, because at this time the child's growth and development determines the future physically, mentally and behaviorally. The world is currently faced with a disease called Covid_19 which is also called the Corona Virus which attacks the respiratory system. Children are the most vulnerable group to the covid_19 virus and if they are exposed it will greatly disrupt the child's growth and development. (Kompas, May 2020) One of the efforts to prevent growth disorders in infants and toddlers is to monitor growth and development even during the Covid_19 pandemic. Community service activities were carried out in Tanjungsari village in June-July 2020. Of the 22 children who were monitored for growth and development, most of them were normal, namely 17 children and 5 children who were not normal. KPSP examination 19 children in appropriate criteria and 3 children in questionable development criteria. TDL, TDD, KMME, CHAT and GPPH examinations are all within normal criteria
\end{abstract}

\section{Keywords: SDIDTK, Covid_19, Community Service}

\begin{abstract}
Abstrak
Tumbuh kembang pada masa bayi dan balita adalah proses yang sangat penting bagi kehidupan seseorang. Masa lima tahun pertama ini biasa disebut dengan golden periode, karena pada masa ini tumbuh kembang anak menentukan masa depan secara fisik, mental maupun perilaku. Dunia saat ini sedang dihadapkan dengan adanya penyakit yang bernama Covid_19 yang juga disebut Virus Corona yang menyerang sistem pernapasan. Anak merupakan kelompok yang paling rentan terhadap virus covid_19 dan jika terkena maka akan sangat mengganggu tumbuh kembang anak. (Kompas, Mei 2020) Salah satu upaya untuk mencegah adanya gangguan tumbuh kembang pada bayi dan balita adalah dengan melakukan pemantauan tumbuh kembang walapun di masa pandemic Covid_19. Kegiatan pengabdian masyarakat dilaksanakan di desa Tanjungsari pada bulan Juni-Juli 2020. Dari 22 anak yang dilakukan pemantauan tumbuh kembang sebagian besar normal yaitu 17 anak dan yang tidak normal ada 5 anak. Pemeriksaan KPSP 19 anak dalam kriteria sesuai dan 3 anak dalam kriteria perkembangan meragukan. Pemeriksaan TDL, TDD, KMME, CHAT dan GPPH semua dalam kriteria normal
\end{abstract}

Kata Kunci: SDIDTK, Covid_19, Pengabmas 


\section{A. PENDAHULUAN}

Lima tahun pertama masa kehidupan sering disebut dengan "periode keemasan" (golden period) disebut juga "masa kritis" disebut juga dengan "jendela kesempatan" (window of opportunity). Hal ini dikarenakan pada masa ini terjadi sangat singkat dan tidak akan bisa diulang lagi dan juga anak cenderung sangat peka pada lingkungannya. Tumbuh kembang pada masa ini sangat menentukan masa depan anak secara mental, fisik dan perilaku.

Tahun 2012 Ikatan Dokter Anak Indonesia (IDAI) wilayah Jawa Timur melaksanakan pemeriksaan pada anak usia 0-72 bulan sebanyak 2.634. Dari hasil skrening didapatkan 53\% anak mempunyai perkembangan normal sesuai dengn usianya. $13 \%$ anak meraguka (memerlukan pemeriksaan lebih dalam) dan sebanyak 34\% menunjukkan hasil penyimpangan perkembangan. Penyimpangan perkembangan 10\% pada aspek motorik kasar (duduk, berjala). Motorik halus (memegang, menulis) 30\%, bicara dan Bahasa $44 \%$ dan sosialisasi kemandirian sebanyak 16\%. Dari data tersebut menunjukkan perkembangan anak menunjukkan hasil meragukan dan mengalami penyimpangan di Indonesia menunjukkan angka yag cukup besar. Penyebabnya karena orang tua masih minim pengetahuan tentang tahap perkembngan anak dan kurangnya keterampilan dalam pemantauan tumbuh kembang anak. (IDAI Jawa Timur, 2012)

Salah satu upaya untuk mencegah adanya gangguan pertumbuhan perkembangan pada bayi dan balita adalah dengan pemantauan tumbuh kembang walapun di masa pandemic Covid_19. Stimulasi Deteksi Dan Intevensi Dini Tumbuh Kembang (SDIDTK) adalah kegiatan pemeriksaan yang digunakan untuk memantau, menjaring dan deteksi dini adanya penyimpangan terhadap pertumbuhan dan perkembangan balita dan anak pra sekolah. Upaya pencegahan, intervensi, stimulasi perkembngan dan upaya pemulihan merupakan kegiatan SDIDTK yang bisadiberikan sedini mungkin untuk mempersiapkan generasi mendatang yang berkualitas.

\section{B. PELAKSANAAN DAN METODE}

Kegiatan pemantauan SDIDTK dilaksanakan di Desa Tanjungsari Kecamatan Boyolangu Kabupaten Tulungagung pada bulan Juni-Juli 2020. Jumlah anak yang dilakukan pemantauan sebanyak 22 anak dengan latar belakang orang tua sebagai ibu rumah tangga dan pekerja swasta. Pelaksanaan kegiatan meliputi: 1) Anamnesa, 2) Pemeriksaan SDIDTK dilaksanakan selama 10 hari mulai tanggal 6-15 Juli 2020 dengan ikut posyandu yang dilaksanakan di balai desa Tanjungsari dan melakukan kunjungan rumah pada baita yang tidak hadir pada saat pelaksaan posyandu, 3) Pemberian asuhan kebidanan, 4) penyuluhan tentang pembuatan oralit dan formula, 5) membantu kegiatan imunisasi.

\section{HASIL DAN PEMBAHASAN}

Pelaksanaan kegiatan dilaksanakan secara bertahap yang di bantu oleh bidan desa dan kader kesehatan. Pada pelaksanaan anamnesa tidak ditemukan masalah dan ibu sangat kooperatif. Dari 22 anak 13 anak berjenis kelamin perempuan dan 9 anak laki-laki yang usianya mulai 24-72 bulan. 
Pemeriksaan pertumbuhan dengan pengukuran tinggi badan (TB), penimbangan berat badan (BB) didapatkan status berat badan anak dalam kritea normal berjumlah 17 anak, berat badan kurang 3 anak dan 2 anak berat badan lebih.

Pemeriksaan perkembangan dengan menggunakan Kuesioner Pra Skrining Perkembangan (KPSP) yang diberikan sesuai usia anak dari 22 anak yang mengalami perkembangan dalam kriteria sesuai berjumlah 19 dan yang mengalami kriteria perkembangan meragukan ada 3 anak. Pemeriksaan TDL (test daya lihat) dan TDD (test daya dengar) KMME, CHAT dan GPPH dari 22 anak semua dalam kategori Norma.

Hasil dari kegiatan pemeriksaan maka dapat disimpulkan bahwa dalam Stimulasi, Deteksi dan Intervensi Dini Tumbuh Kembang (SDIDTK) secara keseluruhan sebagian besar dalam kondisi kategori normal, hanya ada sebagian kecil anak yang mengalami kondisi yang tidak normal yaitu berat badan kurang 3 anak dikarenakan anak sulit makan dan 2 anak berat badan lebih.

Pemeriksaan KPSP mengalami kriteria perkembangan meragukan ada 3 anak hal ini disebabkan karena anak sulit diajak komunikasi dalam pemeriksaan karena masih pertama kali kenal dengan pemeriksa. Hal ini menyebabkan anak menjadi malu dan kadang tidak mau melakukan gerakan yang harus dilakukan sesuai dengan panduan skrining KPSP. Anak yang mempunyai kriteria meragukan berdasarkan hasil skrining dengan KPSP sebaiknya dilakukan stimulasi perkembangan secara rutin dan berkelanjutan. Sedangkan pada anak yang sulit makan bisa di gantikan dengan pemberian formula pada anak untuk pengganti nutrisi yang di butuhkan oleh anak. Pada waktu pemberian penyuluhan ibu sangat antusias dalam mendengarkan dan mau melakukan ketika suatu saat anak malas atau sulit makan dan jika anak mengalami diare mau membuatkan oralit untuk penanganan awal untuk mencegah terjadinya dehidrasi.

\section{PENUTUP}

\section{Simpulan}

Status pertumbuhan anak sebagian besar adalah normal yaitu 17 anak dan yang tidak normal ada 5 anak. Hasil pemeriksaan KPSP 19 anak dalam kriteria sesuai dan dalam kriteria perkembangan meragukan ada 3 anak dan untuk pemeriksaan TDL, TDD, KMME, CHAT dan GPPH semua dalam kriteria normal

\section{Saran}

Kegiatan pemeriksaan SDIDTK ini sebaiknya di agendakan secara berkelanjutan dalam upaya peningkatan kesehatan Tumbuh Kembang anak. Adanya tindak lanjut dari Puskesmas setempat dari temuan hasil pemeriksaan demi peningkatan kesehatan anak jika ada penyimpakan tumbuh kembang anak. 
Ucapan Terima Kasih

Ucapan terimaksih kasi sampaikan kepada Pemerintah Daerah Desa Tanjungasari Kecamatan Boyolangu Kabupaten Tulungagung, kader kesehatan dan bidan desa yang banyak membantu terselenggaranya kegiatan ini

\section{E. DAFTAR PUSTAKA}

Ikatan Dokter Indonesia (IDAI) Jawa timur, 2012. Deteksi Dini Tanda dan Gejala Penyimpangan Pertumbuhan dan Perkembangan Anak. IDAI. Surabaya. Hal 116-117

Kompas.2020.covid19.Jakarta https://www.kompas.com/sains/read/2020/05/22/120200423/risetterbaru-covid-19-temuan-gerbang-masuknya-virus-corona-ke-selhingga.. Diakses tanggal 22 mei 2020. Jam 10.00

Sunartyo, N. 2018. Panduan Merawat Bayi dan Balita Agar Tumbuh Sehat dan Cerdas. Salemba. Yogyakarta. 117-120

Shaleh, A.Q. 2014. Panduan Lengkap Mendeteksi, Memahami, dan Mengatasi Masalah-Masalah Kesehatan Anak Secara Medis dan Psikologis. Andik.Yogyakarta. 57-59

Politeknik, K.M. 2014. Pengaruh Permainan Stimulasi Terhadap Perkembangan Konsep Diri Warga Binaan Pemasyarakat Anak di Lembaga Pemasyarakatan Anak Kota Blitar. Jurnal Kesehatan. Volume 2 No.2: $53-113$ 